\title{
Dynamics of soluble extracellular polymeric substances and transparent exopolymer particle pools in coastal ecosystems
}

\author{
Cécile Klein ${ }^{1}$, Pascal Claquin ${ }^{1, *}$, Alexandrine Pannard ${ }^{1,2}$, Camille Napoléon ${ }^{1}$, \\ Bertrand Le Roy ${ }^{1}$, Benoît Véron ${ }^{1}$
}

${ }^{1}$ UMR100 UCBN-Ifremer Physiologie et d'Ecophysiologie des Mollusques Marins, Université Caen Basse-Normandie, 14032 Caen Cedex, France

${ }^{2}$ UMR CNRS 6553 - ECOBIO, Université de Rennes, 35042 Rennes, France

\begin{abstract}
Time series of soluble extracellular polymeric substance (S-EPS) and transparent exopolymer particle (TEP) fractions, as well as biological, physical and chemical parameters, were studied in natural phytoplankton assemblages at 2 macrotidal sites located in the English Channel for 3 yr. The first site, the Bay des Veys (BDV), is sheltered from prevailing winds and influenced by a high river discharge, whereas the second, Lingreville-sur Mer (LGV), is exposed to the open ocean and to dominant winds. At both sites, the highest TEP concentrations were measured in spring and summer (1735 and $3604 \mu \mathrm{g}$ equiv X $\mathrm{l}^{-1}$ at BDV and LGV, respectively) and were correlated with phytoplankton biomass and nitrogen concentrations. During the autumn and winter, TEP dynamics were not related to phytoplankton dynamics but appeared controlled by hydrodynamics. In contrast to TEP concentrations, S-EPS did not present any seasonal dynamics and was not correlated with TEP variations. The highest amount of S-EPS was recorded in spring at LGV (25.8 mg equiv. glucose $\mathrm{l}^{-1}$ ) and in summer at BDV (26.4 mg equiv. glucose $\mathrm{l}^{-1}$ ). The S-EPS pool was separated in 2 fractions according to the molecular weight: low (LW) and high (HW). The LW fraction was produced in higher quantity than the HW fraction, and with larger temporal fluctuations. Therefore, both S-EPS fractions seem controlled by different environmental parameters depending on the season and on the studied ecosystem. The different dynamics observed for TEP and S-EPS confirm the complexity of carbon excretion processes in phytoplankton, and the results reveal different metabolic pathways and different origins for these carbon excretions.
\end{abstract}

KEY WORDS: Transparent exopolymer particles · TEP · Soluble EPS $\cdot$ Diatoms $\cdot$ Eastern English Channel $\cdot$ Environmental parameters

\section{INTRODUCTION}

In aquatic environments, extracellular polymeric substances (EPS) are abundant and are excreted by many organisms, in particular phytoplankton. Because of their sticky nature, these substances are a key factor in the aggregation and sedimentation dynamics of marine particles (Engel 2000, Passow 2002) and can influence sedimentation of phytoplankton blooms (Thornton 2002). EPS can stick together mineral parti- cles, phytoplankton cells, organic detritus and clay, thus leading to the formation of large aggregates that sink rapidly to the sediment in shallow ecosystems or in deep layers of the ocean (Kiorbøe \& Hansen 1993, Passow \& Alldredge 1995b). High concentrations of polysaccharides are usually associated with high phytoplankton biomass, especially with blooms dominated by diatoms (Passow \& Alldredge 1995b, Mari \& Burd 1998, Passow et al. 2001). However, diatoms are not the only source of marine snow formation, even if they 
contribute the largest part of it (Thornton 2002). Indeed many aquatic organisms generate a large amount of extracellular mucilage, e.g. other microalgae groups (e.g. dinoflagellates, green algae and coccolithophorids), macroalgae, bacteria and zoobenthos (Passow 2002).

Besides the aggregation properties of EPS, these excretions are involved in cell protection (Shimada et al. 1997), cell fixation mechanisms (Welch et al. 1999), nutrient sequestration (Flemming \& Wingender 2001) and migration of microphybenthos (Lind et al. 1997). Moreover, EPS secretions represent a significant source of carbon for microbial, pelagic and benthic consumers (Decho 1990, Underwood \& Smith 1998) including heterotrophic flagellates (Tranvik et al. 1993), planktonic tunicates (Flood et al. 1992), euphausiids (Passow \& Alldredge 1999) and copepods (Decho \& Moriarty 1990). However, EPS may also negatively affect grazing of copepods (Prieto et al. 2001, Dutz et al. 2005) and euphasiids (Passow \& Alldredge 1999). Thus, they play an important role in microbial loops (Decho 1990, Passow 2002).

EPS are predominantly composed by polysaccharides, which are present in the ocean in large quantities and various forms (Hoagland et al. 1993). The production of EPS is mainly known in the form of stalks, tubes, apical pads, adhering films and cell coasting including cells walls and capsules (Hoagland et al. 1993). They can be free or strongly attached to cells (Passow 2002). The main part of EPS is represented by the free fraction, which is constituted of extracellular soluble carbohydrates (S-EPS) (Underwood et al. 1995, 1999, Staats et al. 1999), and by a particulate fraction (Thornton 2002) called transparent exopolymer particles (TEP) (Alldredge et al. 1993). The chemical nature of both fractions is different. S-EPS are mainly made up of galactose and glucuronic acid (De Brouwer et al. 2002), whereas the TEP fraction is mainly composed of fucose and rhamnose (Passow 2002). During the present study, the S-EPS pool was quantified using a method that measures the neutral polysaccharides (Dubois et al. 1956), whereas the TEP correspond to the acidic polysachharide fraction (Passow \& Alldredge 1995a). S-EPS can be separated in 2 pools according to polysaccharide molecular weight: the low molecular weight (LW) pool and the high molecular weight (HW) pool. It has been demonstrated that the composition and the production rates of the LW and HW pools in S-EPS vary with environmental conditions, such as light intensity, including darkness (Smith \& Underwood 2000), and nutrient availability (Staats et al. 1999, Underwood et al. 2004). Several authors have demonstrated that nutrient limitation also emphasises TEP production (Staats et al. 2000, Engel et al. 2002, Passow 2002), but it has been shown in many species from various phyla that large TEP production may also occur under nutrient-replete conditions (Claquin et al. 2008).

The properties and distribution of marine snow in the ocean was first investigated by Suzuki \& Kato (1953). The spatial and temporal distributions of EPS fractions have since been determined in some ecosystems. Most of the time these investigations have shown a significant correlation between TEP concentration and phytoplankton dynamics (Hong et al. 1997, Ramaiah \& Furuya 2002, Beauvais et al. 2003, Radic et al. 2005). Nevertheless, some authors did not find any direct correlation between the TEP fraction and phytoplankton biomass (Garcia et al. 2002, Engel 2004). Another study showed that TEP concentrations and phytoplankton biomass were significantly correlated at the beginning of spring but not during winter (Prieto et al. 2006).

Because EPS play a role in phytoplankton fate by influencing bloom sedimentation or grazing (Passow \& Alldredge 1999, Dutz et al. 2005), the seasonal dynamics of EPS have to be studied in coastal areas, particularly in aquaculture zones, where phytoplankton resources are essential. Our study was performed in one of the most important shellfish farming productions area of Western Europe (Normandie, France). Previous studies in this area have demonstrated that phytoplankton assemblages are largely dominated by diatoms (Jouenne et al. 2005, 2007, Pannard et al. 2008), and that oysters (Crassostrea gigas) feed predominantly on phytoplankton and, to a lesser extent, on microphytobenthos and detritus (Marin Leal et al. 2008). Aggregation processes associated with EPS and TEP production may affect the feeding efficiency and the food quality for shellfish and zooplankton (Prieto et al. 2001).

In this context, the objectives of the present study were to describe and compare the seasonal dynamics of S-EPS and TEP in coastal ecosystems and to investigate their controlling factors, in parallel with the phytoplankton dynamics. In order to reach these objectives, we followed the temporal variations of S-EPS and TEP in the eastern (Baie des Veys) and western (Lingreville-sur-mer) English Channel for 3 yr. Correlations between changes in TEP and S-EPS production, phytoplankton dynamics and hydrodynamic factors were investigated using multivariate analyses.

\section{MATERIALS AND METHODS}

Study sites. Samples were collected from 2 large basins located in the English Channel (Normandie, France) (Fig. 1). Both sites are macrotidal coastal ecosystems, with a maximum tidal range of $8 \mathrm{~m}$ and a mean depth of $6 \mathrm{~m}$. They are both characterised by 


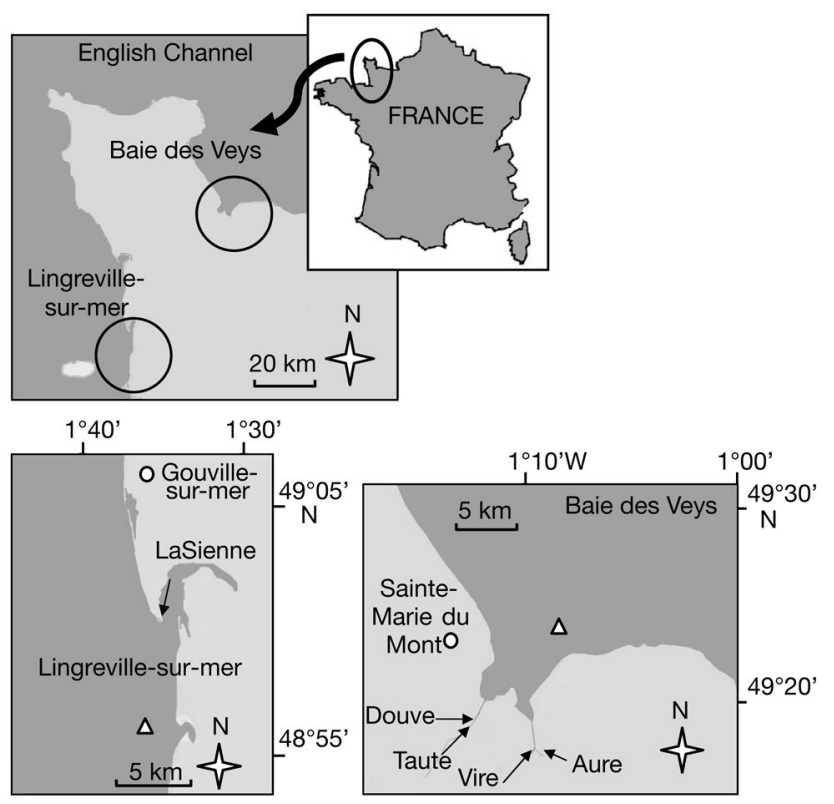

Fig. 1. Location of the sampled sites $(\Delta)$, Baie des Veys (BDV) and Lingreville-sur-mer (LGV) $\mathrm{O}=$ meteorological monitoring station (Pannard et al. 2008)

dense shellfish farming. These areas contrast in terms of nutrient availability and hydrodynamics. The eastern coast of Cotentin (Baie des Veys [BDV]) is protected from prevailing winds because of its location (for details, see Marin Leal et al. 2008) and is largely influenced by river discharge (Jouenne et al. 2005). The western coast (Lingreville-sur-mer [LGV]) is exposed to the westerly winds and is not directly influenced by river discharge because of the low inflow of the river. The LGV site is more influenced by offshore water masses than the BDV site.

Sampling was performed 3 times a week for $3 \mathrm{wk}$ in autumn and spring at each site and monthly between both periods, for 3 yr. Samples were always collected at high tide, at the same location $\left(49^{\circ} 24^{\prime} 50 \mathrm{~N}\right.$, $1^{\circ} 06^{\prime} 50 \mathrm{~W}$ for $\mathrm{BDV}$ and $48^{\circ} 56^{\prime} 29 \mathrm{~N}, 1^{\circ} 35^{\prime} 65 \mathrm{~W}$ for LGV) and at $1 \mathrm{~m}$ depth using a membrane pump. Time between sampling and analysis (or filtrations) varied from a few minutes (photosynthetic parameters, nutrients) to $2 \mathrm{~h}$, with all the analyses performed in triplicate.

Physical and chemical measurements. Vertical profiles of temperature and salinity were measured with a HYDROLAB DS5 probe. Dissolved nutrients - $\mathrm{NO}_{3}$, $\mathrm{PO}_{4}$ and $\mathrm{Si}(\mathrm{OH})_{4}$ - were measured in triplicate using colorimetric methods, according to Aminot \& Kérouel (2007) with a Bran \& Luebbe continuous-flow analyser. Dissolved ammonium $\left(\mathrm{NH}_{4}\right)$ was measured in triplicate manually using a colorimetric method (Aminot \& Kérouel 2004). Suspended particulate matter (SPM) was obtained after filtration of 11 of seawater onto
Whatman GF/F pre-combusted filters $\left(400^{\circ} \mathrm{C}\right)$ and further analyses were performed on a standard weight measurement following the method of Aminot \& Chaussepied (1983). Meteorological data (solar radiation, temperature, rainfall and wind velocity) were monitored by Météo France $15 \mathrm{~km}$ from each sampling site (Sainte-Marie du Mont for BDV, 49 24'12 N, $1^{\circ} 10^{\prime} 06 \mathrm{~W}$, and Gouville-sur-mer for LGV, 49 06' $24 \mathrm{~N}$, $\left.1^{\circ} 36^{\prime} 24 \mathrm{~W}\right)$.

Chlorophyll a. Phytoplankton biomass was estimated from chlorophyll a ( $\mathrm{chl}$ a) measurements, both total and after fractionation, to distinguish the large and the small fraction by filtration on $10 \mu \mathrm{m}$ nylon fibre and on Whatman GF/F glass fibre filters at low vacuum pressure. Chl a was extracted from filters by $90 \%$ acetone overnight in the dark at $4^{\circ} \mathrm{C}$ and then measured by fluorometry (TD-700, Turner Designs) according to Welschmeyer (1994).

Both sampling sites were included in 2 different networks, which also measured chl a concentrations. BDV is included in the REPHY (IFREMER) network and LGV in the SMEL HYDRONOR network. We used the chl a concentration data from these networks in addition to our own data.

Pulse amplitude modulated (PAM) fluorometry. PAM measurements allowed us to estimate the physiological status of microalgae (Parkhill et al. 2001). The maximum energy conversion efficiency, or quantum efficiency of photosystem II (PSII) charge separation $\left(F_{\mathrm{v}} / F_{\mathrm{m}}\right)$, was measured using a WATER/B PAM (Walz) (Schreiber et al. 1986). After a dark adaptation of $15 \mathrm{~min}$, a $3 \mathrm{ml}$ subsample was placed in a darkened measuring chamber. The sample was excited by a weak blue light $\left(1 \mu \mathrm{mol} \mathrm{m} \mathrm{m}^{-2} \mathrm{~s}^{-1}, 470 \mathrm{~nm}, 0.6 \mathrm{kHz}\right.$ frequency) and fluorescence was detected at wavelengths above $695 \mathrm{~nm}$. The blank was performed on filtered water from each sample (GF/F filters). $F_{\mathrm{v}} / F_{\mathrm{m}}$ was calculated by:

$$
F_{\mathrm{v}} / F_{\mathrm{m}}=\left(F_{\mathrm{m}}-F_{0}\right) / F_{\mathrm{m}}
$$

where $F_{0}$ is the minimum fluorescence and $F_{\mathrm{m}}$ is the maximum fluorescence (during a saturating light pulse, $0.6 \mathrm{~s}, 470 \mathrm{~nm}, 1700 \mu \mathrm{mol} \mathrm{m} \mathrm{m}^{-2} \mathrm{~s}^{-1}$ ) of a darkadapted sample (Genty et al. 1989).

Phytoplankton community structure. Phytoplankton species composition was determined as in Pannard et al. (2008). Briefly, $500 \mathrm{ml}$ of water was filtered on a polycarbonate filter using gentle vacuum. Cells were resuspended in $2 \mathrm{ml}$ of filtered water and fixed with glutaraldehyde ( $1 \%$ of final volume). Then cells were counted using light microscopy on Sedgewick-Rafter cells.

Determination of TEP. One litre of seawater was filtered in triplicate onto a $0.4 \mu \mathrm{m}$ polycarbonate filter at gentle vacuum to preserve the phytoplankton cells as 
described by Passow \& Alldredge (1995a). The particular material present on the filter was immediately resuspended in $5 \mathrm{ml}$ of filtered (Whatman GF/F) seawater and centrifuged for $10 \mathrm{~min}$ at $3200 \times \mathrm{g}$. Pellets were stored frozen at $-20^{\circ} \mathrm{C}$ until analysis. Measurements indicated that an average of $3 \%$ of the total TEP concentration (and maximum 5\%) could remain on the filter after resuspension. All TEP data were corrected in order to take in account this average percentage loss.

On the pellets, TEP concentrations were measured following the method from Claquin et al. (2008), which avoids high blank values due to absorption of Alcian Blue on polycarbonate filter and the high variability of the calibration curves. A volume of $2 \mathrm{ml}$ of $0.02 \%$ Alcian Blue prepared in $0.06 \%$ acetic acid was added to a pellet. The sample was centrifuged $(3200 \times g$, $20 \mathrm{~min}$ ) immediately to remove the excess dye. The pellet was rinsed with $1 \mathrm{ml}$ of distilled water and centrifuged several times until obtaining an uncoloured supernatant. A volume of $4 \mathrm{ml}$ of $80 \% \mathrm{H}_{2} \mathrm{SO}_{4}$ was then added to the pellet. After $2 \mathrm{~h}$, the absorption of the supernatant was measured by spectrophotometer at $787 \mathrm{~nm}$. TEP values are expressed as xanthan gum weight equivalent ( $\mu \mathrm{g}$ equiv. $\mathrm{X}^{-1}$ ), calculated by means of a calibration curve realised according to Claquin et al. (2008). A new calibration curve was realised at each season using 12 concentrations (in triplicate).

Determination of EPS: soluble carbohydrate fraction. The soluble fraction of EPS is dissolved in seawater (Underwood et al. 1995). This fraction is obtained after filtration onto a $0.4 \mu \mathrm{m}$ polycarbonate filter. The separation of S-EPS in 2 distinct pools (HW and LW) was performed in triplicate according to Underwood et al. (2004) and De Brouwer \& Stal (2002). S-EPS was then dosed using the colorimetric method of Dubois et al. (1956). A volume of $8 \mathrm{ml}$ of the filtrate was added to centrifuge tube containing $24 \mathrm{ml}$ cold ethanol (75\%) and the S-EPS was allowed to precipitate overnight at $-20^{\circ} \mathrm{C}$. After centrifugation at $3200 \times g$ for $15 \mathrm{~min}$, supernatant representing S-EPS LW and pellets representing S-EPS HW were separated and placed in incubator at $50^{\circ} \mathrm{C}$ for drying. Dried samples were resuspended in $x \mathrm{ml}$ of distilled water for HW and LW, respectively. A volume of $x \mathrm{ml}$ of phenol (5\%) and $5 x$ $\mathrm{ml}$ of $\mathrm{H}_{2} \mathrm{SO}_{4}$ was added and, after $30 \mathrm{~min}$, the EPS concentrations were measured at $485 \mathrm{~nm}$ by spectrophotometer ( $x=3$ for HW and $x=5$ for LW). S-EPS values are expressed as glucose (mg equiv. glucose $\mathrm{l}^{-1}$ ). EPS values are expressed per chl a unit (mg equiv. glucose $\mathrm{mg}^{-1} \mathrm{chl}$ a).

Numerical analyses. In order to draw a parallel between the environmental and biological parameters and the species composition (see Table 1), canonical
Table 1. Predictive environmental variables, supplementary biological variables and species used in the canonical correspondence analyses. HW: high molecular weight; LW: low molecular weight; S-EPS: soluble extracellular polymeric substances; SPM: suspended particulate matter; TEP: transparent exopolymer particles

\begin{tabular}{|c|c|}
\hline Variables & Species \\
\hline Predictive environmental & Asterionellopsis glacialis \\
\hline Light & Chaetoceros spp. \\
\hline Rain & Ditylum sp. \\
\hline Wind & Fragilaria sp. \\
\hline Temperature & Guinardia spp. \\
\hline $\mathrm{PO}_{4}$ & Gymnodinium spp. \\
\hline $\mathrm{NO}_{3}$ & Leptocylindrus danicus \\
\hline $\mathrm{NH}_{4}$ & Nitzschia longissima \\
\hline $\mathrm{Si}(\mathrm{OH})_{4}$ & Nitzschia sp. \\
\hline SPM & Odontella spp. \\
\hline Supplementary biological & Paralia marina \\
\hline Chl a (large) & Phaeocystis qlobosa \\
\hline Chl a (small) & Pseudo-nitzschia spp. \\
\hline TEP $1^{-1}$ & Rhabdonema sp. \\
\hline $\mathrm{TEP} / \mathrm{chl} a$ & Rhizosolenia imbricata \\
\hline S-EPS (HW) & Skeletonema marinoi \\
\hline S-EPS (LW) & $\begin{array}{l}\text { Thalassionema nitzschioides } \\
\text { Thalassiosira rotula }\end{array}$ \\
\hline
\end{tabular}

correspondence analyses (CCA) were performed for each site and for each season using the program CANOCO 4.5 (ter Braak \& Verdonschot 1995). Species data were $\ln$-transformed $[\ln (\mathrm{x}+1)]$ as these variables may have an asymmetric distribution due to exponential growth when conditions are favourable (ter Braak \& Smilauer 2002). CCA is an efficient ordination technique when a Gaussian relationship between species and the environmental gradients is expected (ter Braak 1986). This constrained analysis extracts the best environmental gradients that explain a maximum of the variability of species data. Biological variables (such as S-EPS and TEP concentration) were added as supplementary variables to the CCA, and were thus correlated with the canonical axis (which is a linear combination of environmental parameters) on the plot.

\section{RESULTS}

\section{Nutrients, chl $a$, TEP and S-EPS}

Nutrient concentrations determined during the study showed classic trends of temperate nutrient-rich coastal ecosystems (Jouenne et al. 2005, Pannard et al. 2008). Each year, winter nitrate concentrations were $\sim 30 \mu \mathrm{M}$ at both BDV and LGV. Nitrates decreased throughout the spring and reached concentrations at the detection limit during summer $(<0.01 \mu \mathrm{M})$ (data not shown). Changes in silicate concentrations showed the 
same trend as the concentrations of nitrate, characterised by high values in winter and low values in summer (data not shown). Phosphate concentrations remained low throughout the $3 \mathrm{yr}$ studied and increased slightly during the winter at both sites (data not shown). Ammonium concentrations remained low during the winter and spring and increased from summer to autumn for the $3 \mathrm{yr}$ studied at BDV (data not shown). At LGV, ammonium concentrations were highest during the spring (up to $3.2 \mu \mathrm{M}$ ) and remained low during the summer with a slight increase during fall.

The total chl a data are presented for each site in Fig. 2 and Table 2. Concentrations ranged from 0.7 to $8.1 \mathrm{\mu g} \mathrm{l}^{-1}$ at LGV and from 0.6 to $18.9 \mu \mathrm{g} \mathrm{l}^{-1}$ at BDV. The highest values at both sites were observed in spring 2008. Chl a concentrations observed at both sites during sampling periods were in accordance with annual data from the REPHY IFREMER and HYDRONOR SMEL networks (Fig. 2). At BDV, chl a showed higher concentrations in spring than in autumn, except in 2007 when higher chl a concentrations were observed in autumn. At LGV, the spring and the autumnal chl a concentration variations were roughly the same except for spring 2008, which showed a large increase Annual chl a concentrations were lower at LGV than at BDV, 2.95 and $4.3 \mu \mathrm{g} \mathrm{l}{ }^{-1}$, respectively (Table 2 ). The annual chl a concentrations at LGV were two-thirds of those at BDV, indicating that environmental conditions were more favourable to bloom development at BDV than at LGV. At both sites, large cells dominated phytoplankton communities over the $3 \mathrm{yr}(62.3 \%$ at BDV and $57.0 \%$ at LGV) and followed the same evolution as the total biomass $\left(\mathrm{r}^{2}=\right.$ $0.94, p<0.0001$ at BDV and $\mathrm{r}^{2}=0.92, \mathrm{p}<0.0001$ at LGV) (data not shown).

TEP concentrations were measured during the whole sampling period at each site (Fig. 3, Table 2). TEP abundance is expressed in $\mu \mathrm{g}$ equiv. $\mathrm{Xl}^{-1}$ and as a

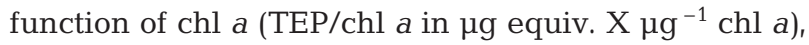
as is frequently observed in the literature. TEP abundance varied largely at both sites: from 36.9 to $1735 \mu \mathrm{g}$ equiv. $\mathrm{Xl}^{-1}$ at BDV with a mean of $280.7 \mu \mathrm{g}$ equiv. $\mathrm{Xl}^{-1}$ and from 26.4 to $3604.5 \mu \mathrm{g}$ equiv. $\mathrm{X}^{-1}$ at LGV with a mean of $452.4 \mu \mathrm{g}$ equiv. $\mathrm{X} \mathrm{l}^{-1}$. Generally, during high TEP concentration periods, the highest values were measured in LGV; nevertheless, overall TEP concentrations at both sites were not significantly different ( $t$-test, $\mathrm{p}=0.0584)$. At BDV, the highest TEP concentrations were recorded during spring 2006, after which concentrations were smaller and increased in spring and autumn. At LGV, the observed concentrations were quite variable with a tendency to increase in spring. The highest peak was observed at the beginning of 2008 , followed by a sudden decrease. The

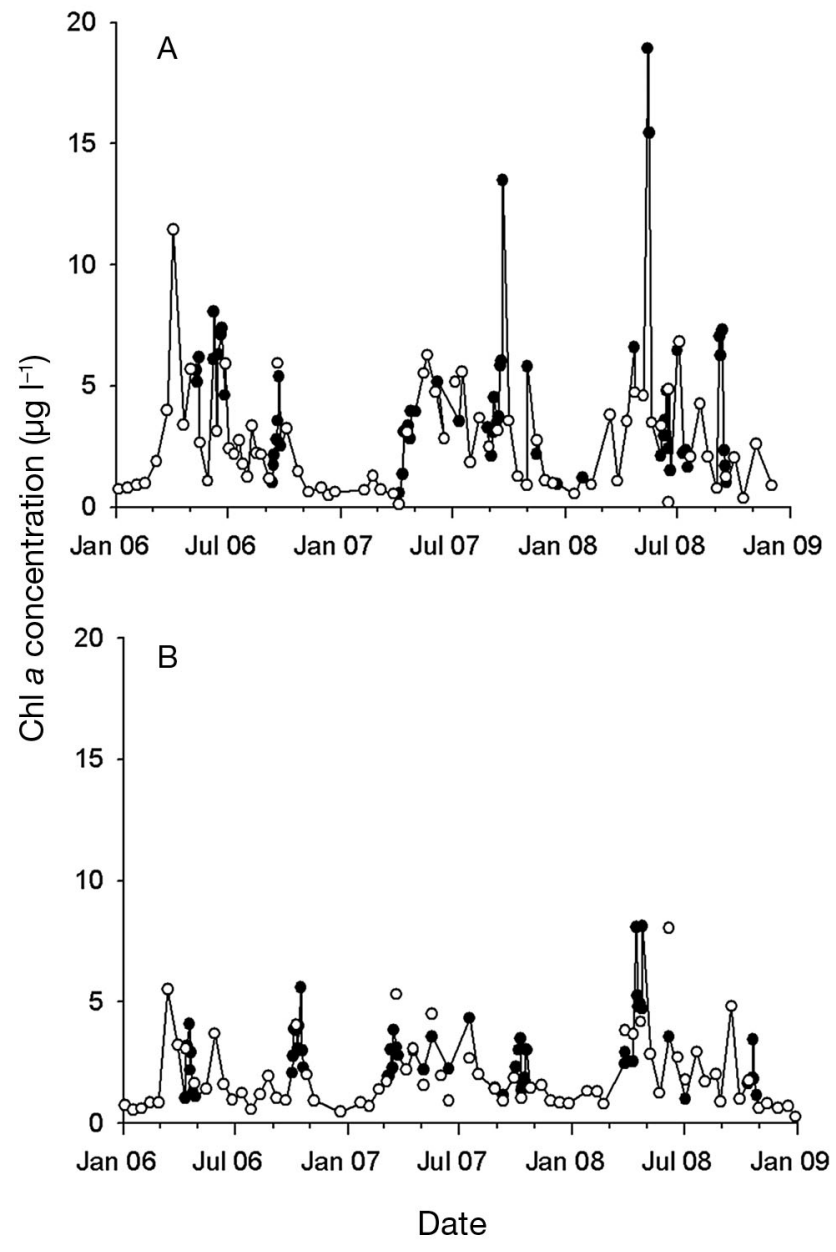

Fig. 2. Seasonal variation of total chlorophyll a during the $3 \mathrm{yr}$ of study (๑) at (A) BDV (O: data from the IFREMER REPHY network, in particular from the Geffosses station) and (B) LGV (O: data from the SMEL HYDRONOR network)

observed pattern changes when the production of TEP is expressed per unit chl a. At BDV, the TEP/chl a ratios were relatively low (from 9.4 to $677 \mu$ g equiv. $\mathrm{X} \mathrm{\mu g}^{-1}$

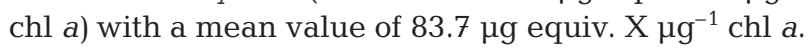
In contrast, at LGV the TEP/chl a ratios were higher (from 8.8 to $1239 \mu$ g equiv. $\mathrm{X} \mathrm{\mu g}^{-1} \mathrm{chl}$ a) with a mean of $186 \mu \mathrm{g}$ equiv. $\mathrm{X} \mu^{-1} \mathrm{chl} a$. The highest values appeared from December 2007 to March 2008.

The temporal evolution of S-EPS (LW and HW) during sampling is presented for both sites in Fig. 4 and Table 2. The variation of both EPS pools did not show any specific pattern at either site. The highest amount of EPS was produced in May 2007 at LGV $(25.8 \mathrm{mg}$ equiv. glucose $\mathrm{l}^{-1}$ ) and in July 2007 at BDV (26.4 mg equiv. glucose $\mathrm{l}^{-1}$ ). Specifically, the LW pool was always higher in concentration than the HW pool at both sites. Concentrations of LW at BDV ranged from 5.5 to $25.1 \mathrm{mg}$ equiv. glucose $\mathrm{l}^{-1}$ and from 0.6 to 
Table 2. All parameters obtained at Baie des Veys (BDV) and Lingreville-sur-mer (LGV), mean, minimum and maximum values. See Table 1 for abbreviations

\begin{tabular}{|c|c|c|c|c|c|c|c|}
\hline \multirow[t]{2}{*}{ Parameter } & \multirow[t]{2}{*}{ Units } & \multicolumn{3}{|c|}{ BDV- } & \multicolumn{3}{|c|}{$-\mathrm{LGV}$} \\
\hline & & Mean & Min. & Max. & Mean & Min. & Max. \\
\hline Light & $\mathrm{J} \mathrm{cm}^{-2}$ & 1162.88 & 20.83 & 3081.00 & 930.92 & 18.25 & 2787.00 \\
\hline Rain & $\mathrm{mm}$ & 2.66 & 0.00 & 47.10 & 1.35 & 0.00 & 16.20 \\
\hline Wind & $\mathrm{m} \mathrm{s}^{-1}$ & 3.65 & 2.10 & 6.80 & 5.30 & 1.80 & 11.30 \\
\hline Temperature & ${ }^{\circ} \mathrm{C}$ & 15.27 & 8.55 & 19.21 & 13.02 & 6.70 & 17.70 \\
\hline $\mathrm{PO}_{4}$ & $\mu \mathrm{mol} \mathrm{l} \mathrm{l}^{-1}$ & 0.41 & 0.01 & 2.84 & 0.29 & 0.01 & 0.90 \\
\hline $\mathrm{NO}_{3}$ & $\mu \mathrm{mol} \mathrm{l} \mathrm{l}^{-1}$ & 6.38 & 0.04 & 35.96 & 6.20 & 0.08 & 31.13 \\
\hline $\mathrm{NH}_{4}$ & $\mu \mathrm{mol} \mathrm{l} \mathrm{l}^{-1}$ & 1.22 & 0.01 & 4.79 & 0.59 & 0.00 & 3.17 \\
\hline $\mathrm{Si}(\mathrm{OH})_{4}$ & $\mu \mathrm{mol} \mathrm{l}^{-1}$ & 5.69 & 0.01 & 17.21 & 28.56 & 0.01 & 317.59 \\
\hline SPM & $\mathrm{mg} \mathrm{l}^{-1}$ & 34.29 & 12.90 & 121.76 & 35.85 & 13.30 & 165.26 \\
\hline Chl a (total) & $\mu \mathrm{gl}^{-1}$ & 4.3 & 0.58 & 18.92 & 2.95 & 0.72 & 8.10 \\
\hline Chl a (large) & $\mu \mathrm{g} \mathrm{l}^{-1}$ & 2.38 & 0.08 & 12.28 & 1.61 & 0.07 & 5.95 \\
\hline Chl a (small) & $\mu \mathrm{gl}^{-1}$ & 1.68 & 0.24 & 6.64 & 1.33 & 0.35 & 3.13 \\
\hline TEP $1^{-1}$ & $\mu g$ equiv. $X^{-1}$ & 280.79 & 36.90 & 1735.05 & 452.44 & 26.45 & 3604.52 \\
\hline $\mathrm{TEP} / \mathrm{chl} a$ & $\mu \mathrm{g}$ equiv. $\mathrm{X} \mu \mathrm{g}^{-1} \mathrm{chl} a$ & 83.72 & 9.43 & 677.00 & 186.22 & 8.81 & 1239.13 \\
\hline S-EPS (HW) & $\mu \mathrm{g}$ equiv. glucose $\mathrm{l}^{-1}$ & 1.77 & 0.76 & 3.90 & 1.78 & 0.45 & 6.34 \\
\hline S-EPS (LW) & $\mu \mathrm{g}$ equiv. glucose $1^{-1}$ & 11.68 & 5.52 & 25.14 & 13.18 & 0.69 & 21.90 \\
\hline
\end{tabular}

21.9 mg equiv. glucose $\mathrm{l}^{-1}$ at LGV, whereas concentrations of HW ranged from 0.7 to $3.9 \mathrm{mg}$ equiv. glucose $\mathrm{l}^{-1}$ at BDV and from 0.4 to $6.3 \mathrm{mg}$ equiv. glucose $\mathrm{l}^{-1}$ at LGV. The mean concentrations of HW and LW were almost the same at both sites: 2.01 and $12.19 \mathrm{mg}$ equiv. glucose $\mathrm{l}^{-1}$ for HW and LW, respectively, at LGV, and 1.52 and $12.45 \mathrm{mg}$ equiv. glucose $\mathrm{l}^{-1}$ for HW and LW, respectively, at BDV. More generally, the LW fraction increased largely during spring or early summer and increased slightly during autumn. Although the HW fractions decreased over the 3 yr sampling, no seasonal trend was observed.

\section{Seasonal dynamics}

CCA and correlations were used to relate the TEP and S-EPS (LW and HW) concentrations to environmental variables and species occurrences.

\section{Spring and summer}

The CCA performed on spring and summer LGV data was significant (Monte-Carlo test, p < 0.002) (Fig. 5). The first 2 axis of the CCA together explained $73.3 \%$ of the total variance of the species-environment relationship. Ammonia concentrations and light intensity contributed strongly to the first axis (89.3 and $-70.9 \%$, respectively) and $F_{\mathrm{v}} / F_{\mathrm{m}}$ values were also linked to the first axis (36.9\%). This relationship means that when the ammonia concentrations were high, the physiological status of cells was good. The CCA showed that LW fractions were high when $F_{\mathrm{v}} / F_{\mathrm{m}}$ (i.e. the apparent physiological status of cells) and the ammonia concentrations were low and when the light intensity was high. The chl a concentrations of large cells were strongly associated with the second axis of the CCA $(62.6 \%)$, as were nitrate concentrations $(49 \%)$. Therefore, the bloom of large cells occurred when nitrate concentrations were high. TEP production was also associated with the second axis (50.1\%). Furthermore, TEP concentrations and biomass of large cells were well correlated during this season $\left(\mathrm{r}^{2}=0.56\right.$, $\mathrm{p}=0.002$ ), indicating that large cells were predominantly responsible for the phytoplanktonic origin of TEP. TEP concentrations were also correlated with nitrate concentrations $\left(\mathrm{r}^{2}=0.75, \mathrm{p}<0.0001\right)$. The high TEP values were related to the dominance of Rhabdonema sp., Guinardia spp. and Ditylum sp. The CCA demonstrated that TEP and S-EPS (mainly LW) concentrations had different dynamics, these parameters being indeed almost perpendicular on the CCA. Moreover, both soluble pools (LW and HW) followed different patterns: HW fractions were high when the TEP, chl $a$ and nitrate concentrations were low.

The CCA performed on spring and summer BDV data was significant (Monte-Carlo test, $\mathrm{p}<0.002$ ). The first 2 axes of the CCA together explained $64 \%$ of the total variance of the species-environment relationship. The ordination diagram of species, environmental parameters, and sampling dates is presented in Fig. 6. TEP dynamics followed to a lesser extent the chl a concentrations of large cells, which is confirmed by an $\mathrm{r}^{2}$ value of $0.48(\mathrm{p}<0.001)$. The CCA demonstrated that TEP concentrations were significantly inversely linked 


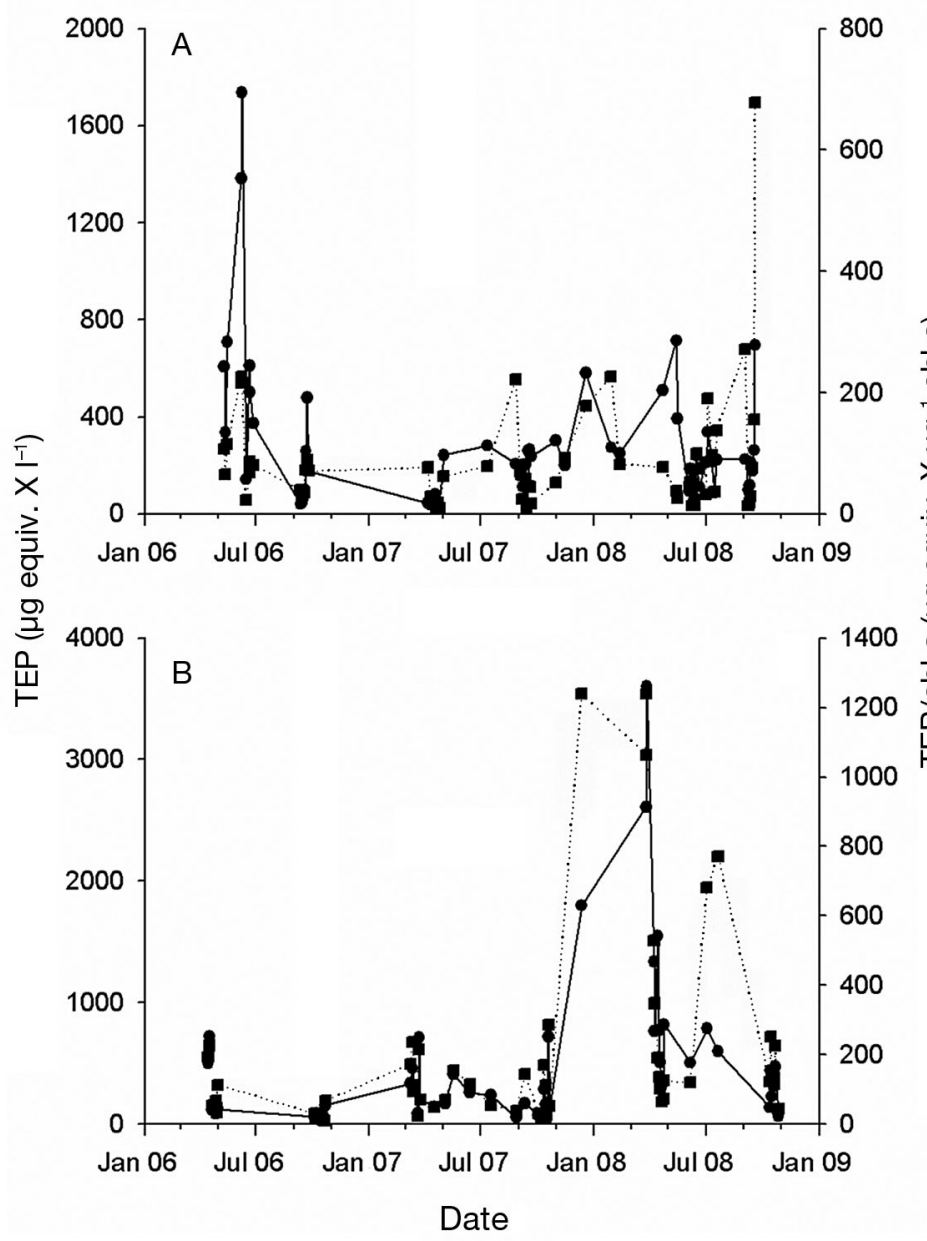

Fig. 3. Time series of TEP during the $3 \mathrm{yr}$ of study at (A) BDV and (B) LGV. Solid lines: absolute TEP concentrations ( $\mu \mathrm{g}$ equiv. $\mathrm{X}^{-1}$; mean values). Dotted lines: relative concentration to $\mathrm{chl}$ a ( $\mu$ g equiv. $\mathrm{X} \mu \mathrm{g}^{-1} \mathrm{chl} a$; mean values)

to silicate concentrations. In this area, during the spring season, the correlation coefficient between TEP and HW $\left(\mathrm{r}^{2}=0.46, \mathrm{p}<0.006\right)$ indicated close relationships between these 2 variables, which is also highlighted by CCA. TEP and HW productions must, therefore, be controlled by the same factors. As for LGV, CCA showed that TEP concentrations were correlated with dissolved nitrogen concentrations, in this case with ammonia $\left(\mathrm{r}^{2}=0.45, \mathrm{p}<0.001\right)$ instead of nitrates. Moreover, HW concentrations were also correlated with ammonia concentrations $\left(\mathrm{r}^{2}=0.8, \mathrm{p}<0.0001\right)$. It is worth noting that these high concentrations of TEP and S-EPS (HW) were associated with 3 diatom species: Rhizosolenia imbricata, Guinardia spp. and Asterionellopsis glacialis. During spring and summer at both sites, TEP production was correlated with phytoplankton biomass, as shown by both CCA and correlations, and was controlled by nitrogen (nitrates or ammonia, depending on site) availability. However, S-EPS did not present the same dynamics for both sites. These SEPS pools (LW and HW) evolved differently at LGV and at BDV and were controlled by different factors within the same site. At LGV, the CCA distinguished the 3 yr (Fig. 5), in contrast to the CCA at BDV (Fig. 6) indicating a higher interannual variability of environmental and biological parameters at LGV than at BDV.

\section{Autumn and winter}

At both sites, the TEP and HW dynamics during autumn and winter could be distinguished from the spring and summer dynamics (Figs. 3 \& 4). At LGV, as for spring and summer, the 2 first axes of the CCA, explaining $82.6 \%$ of the total variance (Monte-Carlo test, $\mathrm{p}<0.002$ ), showed that periods characterised by chl a concentrations of large cells were associated with high nitrate concentrations, which contributed to the first axis (39.4\%; Fig. 7). HW concentrations increased with nitrates $\left(r^{2}=0.40, p<0.05\right)$ and with biomass of large cells $\left(\mathrm{r}^{2}=0.74, \mathrm{p}<0.0001\right)$. TEP production originated from large cells in spring, whereas HW production originated from those cells in autumn. In contrast to spring

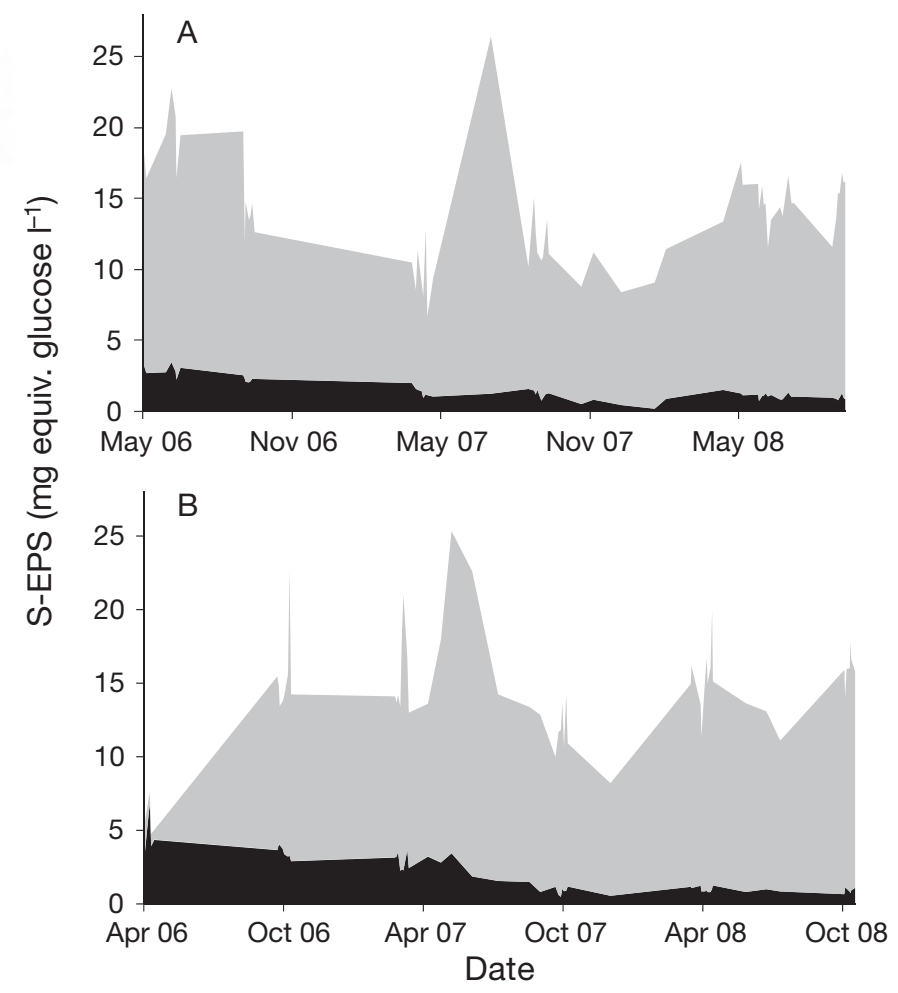

Fig. 4. Time series of soluble EPS (S-EPS; absolute concentrations, mg equiv. glucose $\mathrm{l}^{-1}$ ) during the $3 \mathrm{yr}$ of study at (A) BDV and (B) LGV. High and low molecular weight S-EPS values are represented by black and grey areas, respectively (mean values are given) 


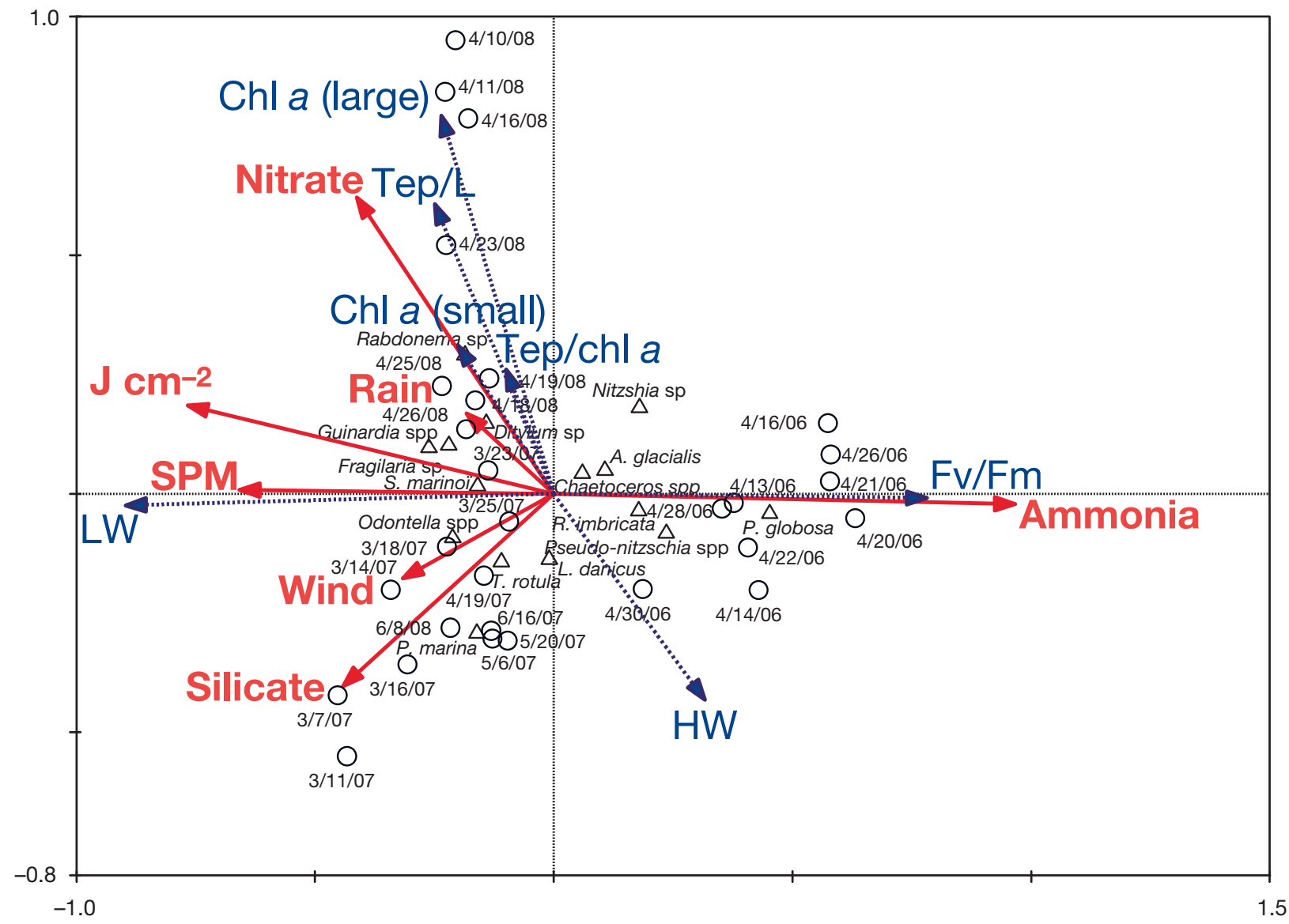

Fig. 5. Canonical correspondence analysis of the community structure at LGV, in spring and summer, showing the relationship between physical, chemical and biological variables (arrows), species abundance $(\Delta)$ and date of sampling $(0)$. Biological variables (blue arrows) were included as supplementary variables. Variables: light intensity $\left(\mathrm{J} \mathrm{cm}^{-2}\right)$; wind speed (wind); nitrate, ammonia, silicate and phosphate concentrations; rain; suspended particulate matter (SPM); chl a concentrations (of large and small biomass); absolute TEP concentrations (TEP $\mathrm{l}^{-1}$ ); TEP concentrations relative to chl a (TEP/chl a), high molecular weight (HW) and low molecular weight (LW) soluble extracellular polymeric substance (S-EPS) concentrations; and the physiological status of phytoplankton communities $\left(F_{\mathrm{v}} / F_{\mathrm{m}}\right)$

and summer, however, TEP concentrations were not correlated with phytoplankton biomass (i.e. chl a concentrations, or total or large chl a) or nitrate concentrations, but with silicate and ammonia concentrations $\left(\mathrm{r}^{2}=0.54, \mathrm{p}<0.006\right.$, and $\mathrm{r}^{2}=0.52, \mathrm{p}<0.01$, respectively) and with SPM $\left(r^{2}=0.60, p<0.002\right)$. These 3 parameters were the main factors that contributed to the second axis $(61.7,85.6$ and $48.13 \%$, respectively). This site is particularly exposed to westerly winds during both autumn and winter and its geographical situation leads to high and frequent resuspension. The effect of nutrient availability on excretion production (TEP and HW) differed between spring and autumn, with TEP concentrations in autumn related to silicate and ammonia concentrations and HW concentrations related to nitrate concentrations. This CCA showed that HW and TEP concentrations were inversely correlated $\left(r^{2}=0.41, p<\right.$
0.04). HW was produced mainly when Thalassionema nitzschioides and Paralia marina development occurred, whereas TEP was produced when Fragilaria sp., Guinardia spp. and Odontella spp. were blooming.

In autumn and winter, chl a concentrations and excretion production at BDV were not controlled by the same factors as in spring and summer. The CCA performed was significant (Monte-Carlo test, $\mathrm{p}<0.01$ ) and the first 2 axes of the CCA together explained $63.9 \%$ of the total variance (Fig. 8). The CCA indicated that nitrogen concentrations as ammonia and nitrate forms contributed largely to the first axis (57.4 and $52.9 \%$, respectively) and that LW fractions were produced when nitrogen concentrations were high. The CCA showed that high TEP concentrations were produced with the occurrence of Thalassiosira rotula, Asterionellopsis glacialis and Paralia marina and that 


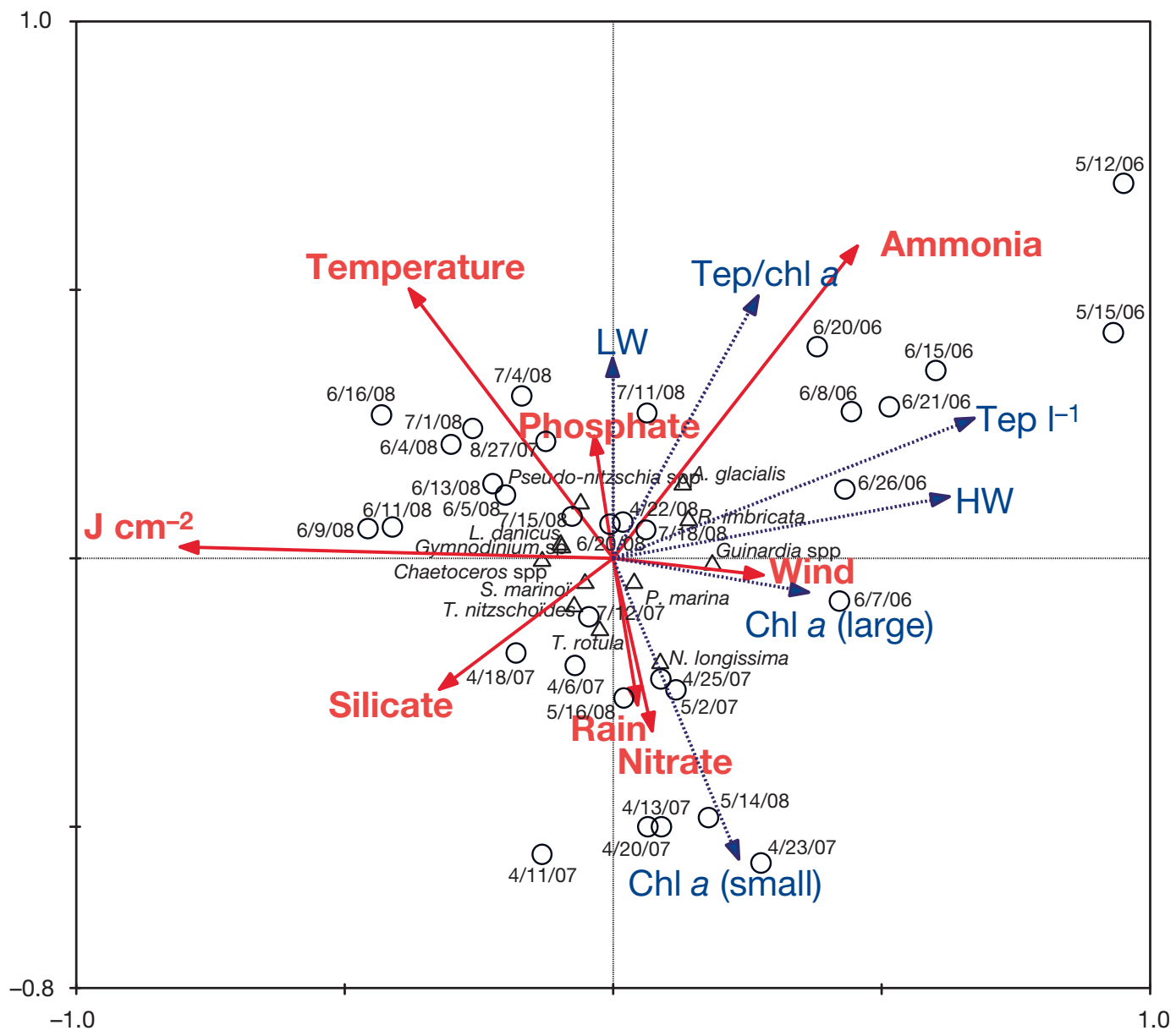

Fig. 6. Canonical correspondence analysis of the community structure at BDV, in spring and summer, showing the relationship between physical, chemical and biological variables (arrows), species abundance $(\Delta)$ and date of sampling (O). Biological variables are as in Fig. 5, except for the addition of water temperature (temperature)

this production was controlled by wind speed and the temperature of water column. These 2 parameters contributed strongly to the second axis (42.6 and $-47.8 \%$, respectively). S-EPS and TEP concentrations again showed contrasting patterns.

As for the spring and summer seasons, the CCA highlighted an influence of nitrogen (i.e. ammonia) availability on TEP production at LGV. However, during autumn and winter at both sites, TEP production was also controlled by hydrodynamics and, particularly, the wind, which induced resuspension (high SPM concentrations) and entailed variations in nutrient availability. As for spring and summer, the LW and HW S-EPS fractions did not present the same dynamics at both sites and they were controlled by different factors within the same site. LGV also showed higher interannual variability of environmental and biological parameters during these seasons than BDV. Indeed, at LGV the CCA again distinguished the $3 \mathrm{yr}$ (Fig. 7), contrary to the CCA at BDV (Fig. 8).

\section{DISCUSSION}

\section{Local processes and mixing of water masses}

Coastal ecosystems are characterised by strong physical and chemical forcings. These systems are the boundary between the open ocean and the continental zones and are characterised by mixing processes with surrounding water masses. Consequently, the water column structure is frequently modified and influences phytoplankton dynamics, which is controlled by abiotic parameters (Margalef et al. 1979, Gentilhomme \& Lizon 1998, Smayda \& Reynolds 2001, Pannard et al. 2008). Both studied areas differed in the hydrodynamic forces that they are exposed to. The local topography of BDV provides shelter from prevailing wind whereas LGV is exposed to the open ocean and dominant winds and presented many gyres, indicating a regular mixing of the water column (Ménesguen \& Gohin 2006). 


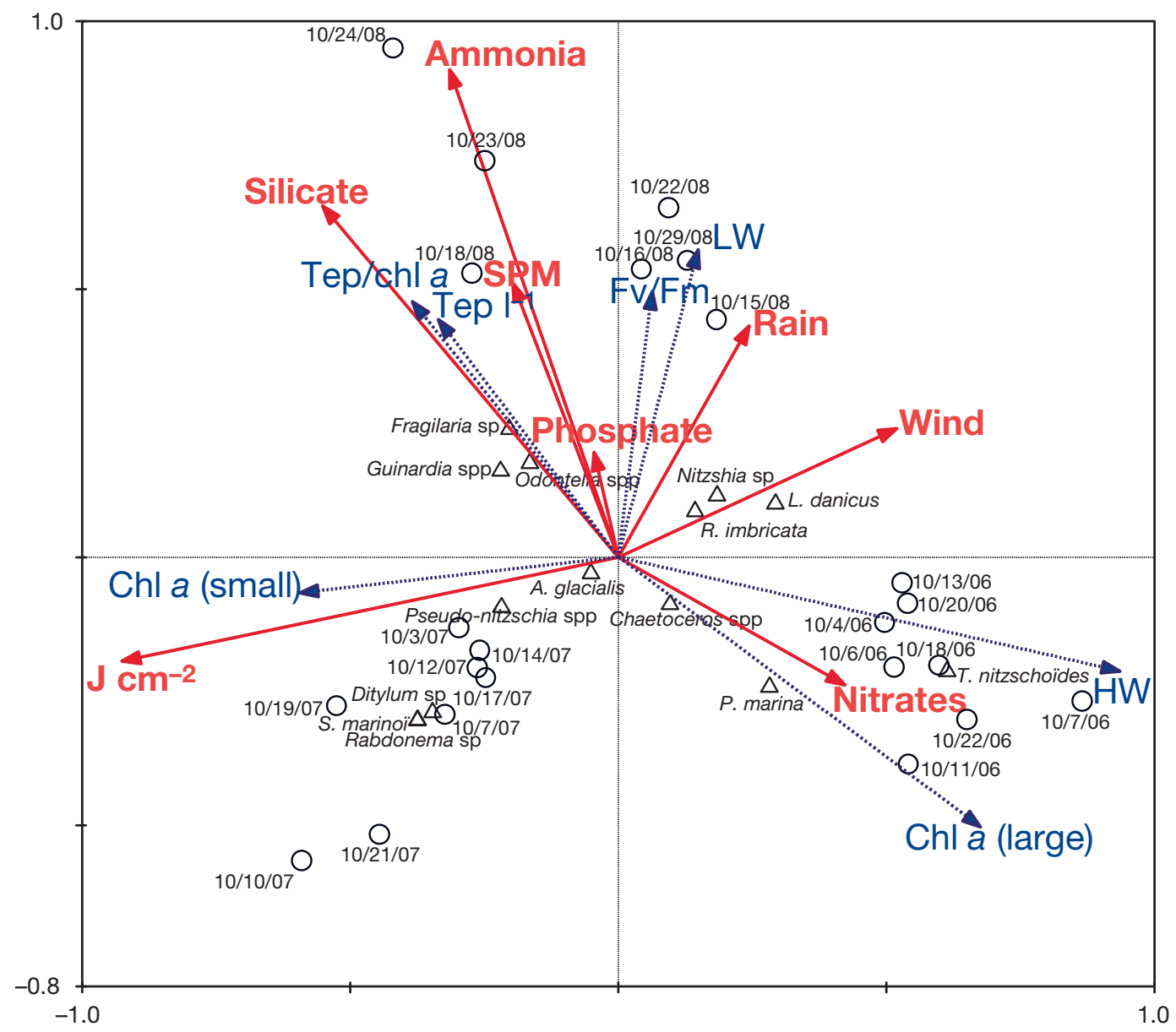

Fig. 7. Canonical correspondence analysis of the community structure at LGV, in autumn and winter, showing the relationship between physical, chemical and biological variables (arrows), species abundance $(\Delta)$ and date of sampling (O). Biological variables are as in Fig. 5

As previously described in this area (Jouenne et al. 2007, Pannard et al. 2008), the spring bloom began in March at LGV and later (April/May) at BDV. The autumnal bloom appeared in September at BDV and in October at LGV. At both sites, the phytoplankton communities were largely dominated by diatoms, as previously reported (Jouenne et al. 2007, Pannard et al. 2008). For all seasons, the dominant species and the community structure of the phytoplankton were different between both sites (data not shown), in accordance with the nutrient availability and the hydrodynamics regime.

\section{Seasonal variability of TEP and S-EPS}

Phytoplankton is known as a major source of excretion of polysaccharides (Passow \& Alldredge 1994, Mari \& Burd 1998, Ramaiah et al. 2001). TEP concen- trations varied greatly at both sites (36.9-1735 $\mu \mathrm{g}^{-1}$ at BDV and 26.4-3604.5 $\mathrm{g} \mathrm{l} \mathrm{l}^{-1}$ at LGV) during the $3 \mathrm{yr}$ of sampling. The minimum values observed at each site were 10 to 20 times lower than those previously observed in the Pacific $\left(<500 \mu \mathrm{g} \mathrm{l}^{-1}\right.$; Passow \& Alldredge 1995b, Li et al. 1998, Passow et al. 2001) and in the northwest Atlantic Ocean $\left(<124 \mu \mathrm{g} \mathrm{l^{-1 }}\right.$; Engel 2004), and the maximum values were similar to those measured in the Ross Sea (2800 $\mu \mathrm{g} \mathrm{l}^{-1}$; Hong et al. 1997). Values observed at each site remained largely lower than those measured in the Northern Adriatic (maximal values were $14000 \mu \mathrm{g} \mathrm{l}^{-1}$; Radic et al. 2005) or in the Baltic Sea (Engel \& Passow 2001). Furthermore, it has been demonstrated that coastal zones present high TEP concentrations (100-3000 $\mathrm{gg} \mathrm{l}^{-1}$; Passow 2002). The coastal ecosystems are often directly influenced by river nutrients inputs. Nutrient increases lead to higher phytoplankton biomass, resulting in high TEP concentrations (Corzo et al. 2000). TEP/chl a 


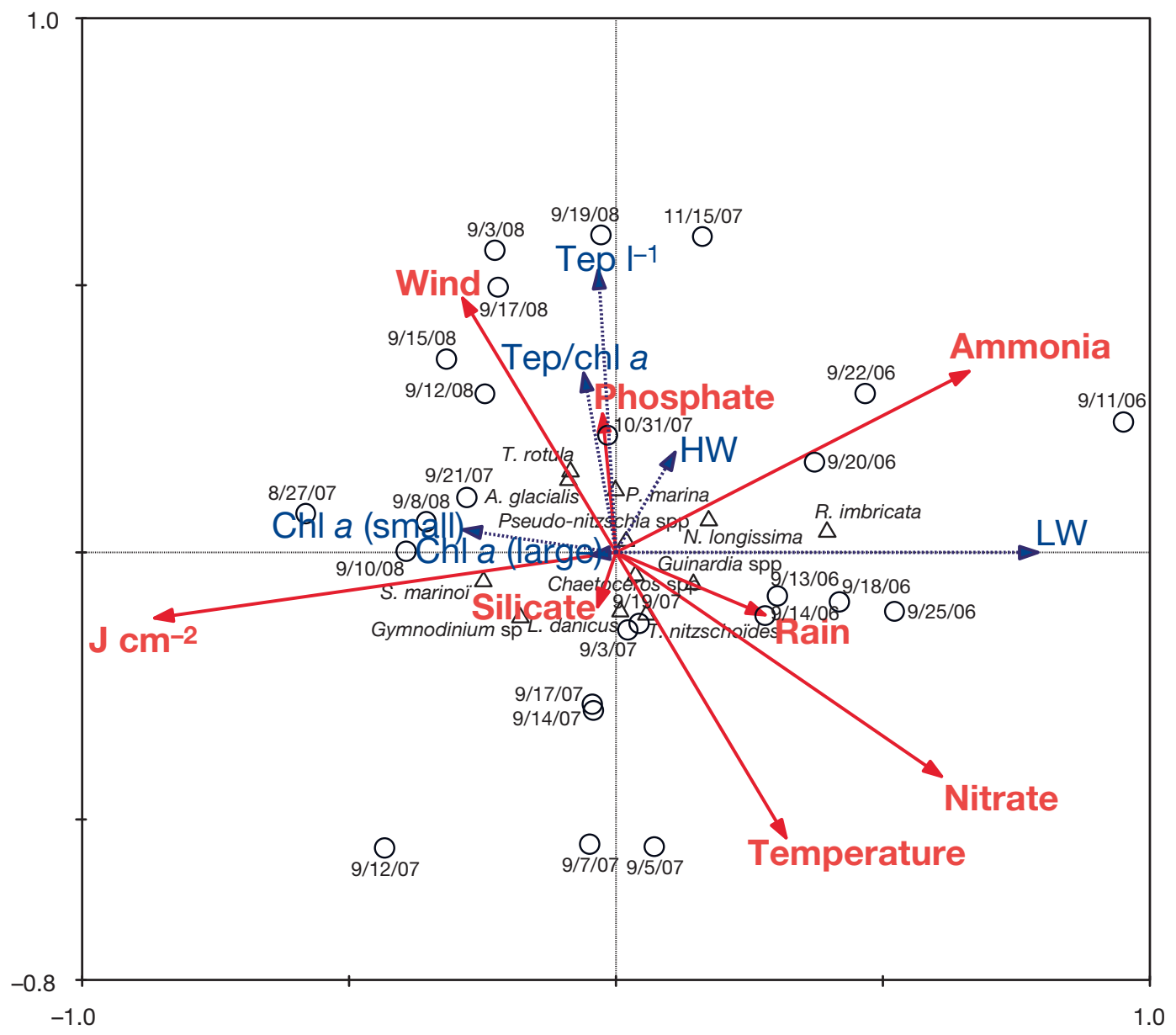

Fig. 8. Canonical correspondence analysis of the community structure at BDV, in autumn and winter, showing the relationship between physical, chemical and biological variables (arrows), species abundance $(\triangle)$ and date of sampling (O). Biological variables are as in Fig. 6

ratios are usually low during phytoplankton blooms, and increase at the end of the bloom when cells become senescent. TEP/chl a ratios obtained during the present study are in accordance with those from previous studies (Prieto et al. 2006, Ortega-Retuerta et al. 2009).

During the spring and summer, TEP concentrations followed the chl a concentrations at both sites, which implies a consistent production of TEP by active growing phytoplankton. This positive correlation between both variables has already been observed in many systems (Passow \& Alldredge 1995b, Hong et al. 1997, Ramaiah \& Furuya 2002, Beauvais et al. 2003, Radic et al. 2005, Prieto et al. 2006). In the present study, the high TEP concentrations resulted from a high number of phytoplankton cells. Further, TEP concentrations at both sites were also correlated with nitrogen concentrations. At LGV, TEP concentrations showed close relationships with nitrate concentrations; at BDV, TEP concentrations were closely correlated with ammonia concentrations. It seems that high nitrogen concentrations enhanced phytoplankton growth and led to an increase in TEP concentrations. Furthermore, because river discharge was significantly higher at BDV than at LGV, nutrient inputs enhanced phytoplankton growth to a greater extent at BDV than at LGV. This result explains why we observed a negative and significant correlation between TEP and silicate concentrations during spring and summer at BDV. Indeed, the diatom bloom consumed the stock of silicates, while the increase in phytoplankton cell numbers led to an increase in TEP production.

During the autumn and winter, at each site, TEP concentrations did not follow the phytoplankton dynamics. The absence of a positive correlation between TEP and chl a concentrations has been already found in some coastal ecosystems (Schuster and Herndl, 1995, Garcia et al. 2002). This trend indicates that the phytoplank- 
ton community did not produce a significant amount of TEP or that TEP was rapidly exported, consumed and/or degraded. Indeed, the amount of TEP depends not only on phytoplankton excretion abundance, but also on the degradation, grazing and turbulence levels (Mari \& Burd 1998, Penna et al. 1999, Kiorbøe 2000, Garcia et al. 2002). Mari \& Burd (1998) used a model to predict TEP concentrations and demonstrated that bacterial degradation and grazing rate are essential to predict the real TEP concentrations in situ. It is well known that bacteria use a considerable fraction of phytoplankton production as a carbon source (Passow et al. 2001, Colombo et al. 2004, Pacobahyba et al. 2004). Furthermore, it has been demonstrated that zooplankton, as grazers, are associated with marine snow in the euphotic zone (Kiorbøe 2000). However, the relationships between TEP dynamics and these 2 processes (degradation and grazing) are still being discussed. Indeed, a previous study has shown a positive correlation between bacteria and TEP concentrations, excluding the degradation of TEP by bacteria (Passow et al. 2001). Other works demonstrated that planktonic copepods did not use TEP as an energy source (Prieto et al. 2001) and that copepod feeding was inhibited by TEP presence (Dutz et al. 2005). Turbulence may also explain the difference observed between phytoplankton and TEP dynamics in autumn/winter. Turbulence level acts on aggregation dynamics and may affect differently the residence time of TEP and phytoplankton in the water column (Garcia et al. 2002). This could explain the uncoupling that we observed between these 2 components during this period. Interpretations of field measurements at LGV and BDV during autumn and winter could be explained by the turbulence level. At both sites, we showed that physical forcing had an impact on TEP production during autumn and winter. Consequently, we can consider that turbulence level explains the autumn and winter dynamics of TEP, through resuspension of exopolysaccharide-rich particles as microphytobenthos biofilm.

The results of the present study also show that TEP was produced by different phytoplankton species depending on season and site. It is known that exopolysaccharides released by microorganisms depend on species, individual physiological state and environmental parameters such as light, carbon dioxide concentrations, nutrient availability, temperature and turbulence regime (Passow 2002, Claquin et al. 2008). Nevertheless, the EPS production varies according to the diatom species; 3 species, Nitzschia sp., Skeletonema marinoi and Thalassiosira spp., observed during the periods of high TEP concentration at both sites have already been described in association with high TEP concentrations in field or laboratory studies (Logan et al. 1995, Prieto et al. 2002, Urbani et al. 2005,
Claquin et al. 2008). However, there is a severe lack of studies on TEP production and on TEP regulation as a function of the phytoplankton species present. This knowledge is essential to understand the dynamics of TEP concentrations in the field.

In contrast to TEP concentrations, the S-EPS pools were not correlated with chl a concentrations, which suggests that a portion of the S-EPS excretions was not related to phytoplankton. These excretions can be produced by bacteria, macro- and micro-phytobenthos, zooplankton and zoobenthos. Because a large part of S-EPS (HW and LW) was due to non-phytoplanktonic excretions, the influence of phytoplankton on the dynamics of S-EPS cannot be well described. TEP dynamics appeared largely driven by phytoplankton development in spring and summer. The TEP pool that we measured was also a good indicator of phytoplankton carbon excretion, which was not the case for S-EPS.

The S-EPS fraction produced by benthic diatoms has been largely described in the literature (Decho 1990, Wolfstein \& Stal 2002, Underwood et al. 2004). However, S-EPS production by planktonic diatoms has been rarely studied. High concentrations of soluble carbohydrates could be present on mudflats, between 50 and $5000 \mathrm{\mu g} \mathrm{g}^{-1}$ sediment (Underwood \& Smith 1998). Several authors have studied the mechanism of EPS production in benthic diatoms as a function of nutrient, light and temperature (Smith \& Underwood 2000, De Brouwer \& Stal 2002, Wolfstein \& Stal 2002, Underwood et al. 2004). It has been demonstrated that the S-EPS production increased in nutrient-limited cultures and that this production can occur under both dark and illuminated conditions (Smith \& Underwood 2000, De Brouwer \& Stal 2002, Wolfstein \& Stal 2002). The chemical composition and physical characteristics of S-EPS changed also significantly with environmental conditions and the physiological status of the diatom cells (De Brouwer \& Stal 2002, Underwood et al. 2004). In the present study, the wind-exposed site (LGV) always showed higher S-EPS concentrations than the protected area (BDV). The concentrations of the HW pool were only correlated with TEP concentrations in the BDV during the spring and summer seasons. For the rest of the sampling, TEP and S-EPS concentrations were not linked. A different pattern of LW and HW S-EPS pools was also observed. This result can be explained by the work of Underwood et al. (2004). They showed that, in the benthic diatom Cylindrotheca closterium, the production of LW and HW SEPS followed different metabolic pathways and were differently affected by environmental factors. In the present study, the S-EPS fraction showed different dynamics depending on the site and the season. No specific pattern was found. In the present study, we 
showed that the S-EPS stocks often do not depend on chl a concentrations; instead, other organisms or biochemical cycles largely influenced the dynamics of this component at both sites.

\section{CONCLUSIONS}

This study demonstrated that the dynamics of TEP and S-EPS were different at the 2 studied sites and varied as a function of seasons, although these 2 pools may have the same precursors. However, it appeared that TEP production was largely related to phytoplankton and nutrient dynamics in spring and summer, whereas hydrodynamic forcings drove TEP concentration variations in autumn and winter. In contrast to the TEP dynamics, which was partly explained by our results, the causes of the variation in the S-EPS pool could not be clearly elucidated. Our results show that the origins of TEP and S-EPS are different, indicating different production patterns. We pointed out that it is necessary to study, in the laboratory, EPS production in planktonic species because previous studies have dealt mainly with benthic diatoms. Besides aiding the understanding of TEP and S-EPS dynamics in coastal ecosystems, the results of the present study will be used in future to estimate the portion of primary production that fuels the phytoplankton-extracellular carbon pool.

Acknowledgements. This study was supported by the Conseil Régional de Basse-Normandie, the Agence de l'Eau-SeineNormandie, the Laboratoire Départemental Franck Duncombe (Conseil du Général du Calvados) and the Syndicat Mixte pour l'Equipement du Littoral (Conseil Général de la Manche). We thank the ERPCB laboratory for technical assistance with nutrient measurements and the CREC marine station for sampling (both at the Université de Caen Basse-Normandie). We thank Dr. J. Fauchot for her constructive comments.

\section{LITERATURE CITED}

Alldredge AL, Passow U, Logan BE (1993) The abundance and significance of a class of large transparent organic particles in the ocean. Deep-Sea Res Part I 40:1131-1140

Aminot A, Chaussepied M (1983) Manuel des analyses chimiques en milieu marin. CNEXO, BNDO/Documentation, Brest, France

Aminot A, Kérouel R (2004) Hydrologie des écosystèmes marins. Paramètres et analyses. Ifremer, Brest

Aminot A, Kérouel R (2007) Dosage automatique des nutriments dans les eaux marines: méthodes en flux continu. Ifremer, Brest

> Beauvais S, Pedrotti ML, Villa E, Lemée R (2003) Transparent exopolymer particle (TEP) dynamics in relation to trophic and hydrological conditions in the NW Mediterranean Sea. Mar Ecol Prog Ser 262:97-109

Claquin P, Probert I, Lefebvre S, Veron B (2008) Effects of temperature on photosynthetic parameters and TEP production in eight species of marine microalgae. Aquat Microb Ecol 51:1-11

Colombo V, Vieira AAH, Moraes G (2004) Activity of glycosidases from freshwater heterotrophic microorganisms on the degradation of extracellular polysaccharide produced by Anabaena spiroides (Cyanobacteria). Braz J Microbiol 3:110-116

> Corzo A, Morillo JA, Rodríguez S (2000) Production of transparent exopolymer particles (TEP) in cultures of Chaetoceros calcitrans under nitrogen limitation. Aquat Microb Ecol 23:63-72

De Brouwer JFC, Stal LJ (2002) Daily fluctuations of exopolymer in cultures of the benthic diatoms Cylindrotheca closterium and Nitzschia sp. (Bacillariophyceae). J Phycol 38:464-472

De Brouwer JFC, Wolfstein K, Stal LJ (2002) Physical characterisation and diel dynamics of different fractions of extracellular polysaccharides in an axenic culture of benthic diatom. Eur J Phycol 32:32-44

Decho AW (1990) Microbial exopolymer secretions in ocean environments: their role(s) in food webs and marine processes. Oceanogr Mar Biol Annu Rev 28:73-153

Decho AW, Moriarty JW (1990) Bacterial exopolymer utilization by a barpacticoid copepod: a methodology and results. Limnol Oceanogr 35:1039-1049

Dubois M, Gilles KA, Hamilton JK, Rebers PA, Smith F (1956) Colorimetric method for determination of sugars and related substances. Anal Chem 28:350-356

Dutz J, Klein Breteler WCM, Kramer G (2005) Inhibition of copepod feeding by exudates and transparent exopolymer particles (TEP) derived from Phaeocystis globosa phytoplankton community. Harmful Algae 4:929-940

Engel A (2000) The role of the transparent exopolymer particles (TEP) in the increase in apparent stickiness during the decline of a diatom bloom. J Plankton Res 22:485-497

Engel A (2004) Distribution of the transparent exopolymer particles (TEP) in the northeast Atlantic Ocean and their potential significance for aggregation processes. DeepSea Res I 51:83-92

- Engel A, Passow U (2001) Carbon and nitrogen content of transparent exopolymer particles (TEP) in relation to their Alcian Blue adsorption. Mar Ecol Prog Ser 219:1-10

Engel A, Meyerhöfer M, v. Bröckel K (2002) Chemical and biological composition of suspended particles and aggregates in the Baltic Sea in summer (1999). Estuar Coast Shelf Sci 55:729-741

> Flemming HC, Wingender J (2001) Relevance of microbial extracellular polymeric substances (EPSs) Part I: structural and ecological aspects. Water Sci Technol 43:1-8

Flood PR, Deibel D, Morris CC (1992) Filtration of colloidal melanin form sea water by planktonic tunicates. Nature 355:630-632

- Garcia CM, Prieto L, Echevarria F, Garcia-Lafuente J, Ruiz J, Rubin JP (2002) Hydrodynamics and the spatial distribution of plankton and TEP in the Gulf of Cadiz (SW Iberian Peninsula). J Plankton Res 24:817-833

Gentilhomme V, Lizon F (1998) Seasonal cycle of nitrogen and phytoplankton biomass in a well-mixed coastal system (Eastern English Channel). Hydrobiologia 361: 191-199

Genty B, Briantais J, Baker NR (1989) The relationship between the quantum yield of photosynthetic electron transport and of quenching chlorophyll fluorescence. Biochim Biophys Acta 990:87-92

> Hoagland KD, Rosowski JR, Gretz MR, Roemer SC (1993) Diatom extracellular polymeric substances: function, fine 
structure, chemistry and physiology. J Phycol 29:537-566

Hong Y, Smith WO Jr, White AM (1997) Studies on transparent exopolymer particles (TEP) produced in the Ross Sea (Antarctica) and by Phaeocystis antarctica (Prymnesiophyceae). J Phycol 33:368-376

Jouenne F, Lefebvre S, Véron B, Lagadeuc Y (2005) Biological and physicochemical factors controlling short-term variability in phytoplankton primary production and photosynthetic parameters in a macrotidal ecosystem (eastern English Channel). Estuar Coast Shelf Sci 65:421-439

Jouenne F, Lefebvre S, Véron B, Lagadeuc Y (2007) Phytoplankton community structure and primary production in small intertidal estuarine-bay ecosystem (eastern English Channel, France). Mar Biol 151:805-825

Kiorbøe T (2000) Colonization of marine snow aggregates by invertebrate zooplankton abundance, scaling and possible role. Limnol Oceanogr 45:479-484

Kiorbøe T, Hansen JLS (1993) Phytoplankton aggregate formation: observations of patterns and mechanisms of cell sinking and the significance of exopolymeric material. J Plankton Res 15:993-1018

Li X, Passow U, Logan BE (1998) Fractal dimensions of small (15-200 $\mu \mathrm{m})$ particles in Eastern Pacific coastal waters. Deep-Sea Res Part I 45:115-131

Lind JL, Heimann K, Miller EA, van Vliet C, Hoogenraad NJ, Wetherbee R (1997) Substratum adhesion and gliding in a diatom are mediated by extracellular proteoglycans. Planta 203:213-221

Logan BE, Passow U, Alldredge AL, Grossart HP, Simon M (1995) Rapid formation and sedimentation of large aggregates is predictable from coagulation rates (half-lives) of transparent exopolymer particles (TEP). Deep-Sea Res II 42:203-214

Margalef R, Estrada M, Blasco D (1979) Functional morphology of organisms involved in red tide, as adapt to decaying turbulence. In: Taylor D, Seliger H (eds) Toxic dinoflagellate blooms. Elsevier, New York, p 89-94

Mari X, Burd A (1998) Seasonal size spectra of transparent exopolymeric particles (TEP) in a coastal sea and comparison with those predicted using coagulation theory. Mar Ecol Prog Ser 163:63-76

Marín Leal JC, Dubois S, Orvain F, Galois R and others (2008) Stable isotopes $\left(\delta^{13} \mathrm{C}, \delta^{15} \mathrm{~N}\right)$ and modelling as tools to estimate the trophic ecology of cultivated oysters in two contrasting environments. Mar Biol 153:673-688

> Ménesguen A, Gohin F (2006) Observation and modelling of natural retention structures in the English Channel. J Mar Syst 63:244-256

Ortega-Retuerta E, Reche I, Pulido-Villena E, Agustí S, Duarte CM (2009) Uncoupled distributions of transparent exopolymer particles (TEP) and dissolved carbohydrates in the Southern Ocean. Mar Chem 115:59-65

Pacobahyba LD, Bianchini I Jr, Vieira AAH, Cunha-Santino MB (2004) The mineralization kinetics of Straurastrum iversenii Nygaard var. americanum. Acta Limnol Brasiliensa 16:391-400

Pannard A, Claquin P, Klein C, Le Roy B, Véron B (2008) Short term variability of the phytoplankton community in coastal ecosystem in response to physical and chemical conditions changes. Estuar Coast Shelf Sci 80:212-224

Parkhill JP, Maillet G, Cullen JJ (2001) Fluorescence-based maximal quantum yield for PSII as a diagnostic of nutrient stress. J Phycol 37:517-529

Passow U (2002) Production of transparent exopolymer particles (TEP) by phyto- and bacterioplankton. Mar Ecol Prog Ser 236:1-12

Passow U, Alldredge AL (1994) Distribution, size and bacter- ial colonization of transparent exopolymer particles (TEP) in the ocean. Mar Ecol Prog Ser 113:185-198

Passow U, Alldredge AL (1995a) A dye-binding assay for the spectrophotometric measurement of transparent exopolymer particles (TEP). Limnol Oceanogr 40:1326-1335

Passow U, Alldredge AL (1995b) Aggregation of diatoms bloom in mecocosm: the role of transparent exopolymer particles (TEP). Deep-Sea Res II 42:99-109

Passow U, Alldredge AL (1999) Do transparent exopolymer particles (TEP) inhibit grazing by the euphausiid Euphausia superba? J Plankton Res 21:2203-2217

Passow U, Shipe RF, Murray A, Pak DK, Brzezinski MA, Alldredge AL (2001) The origin of transparent exopolymer particles (TEP) and their role in the sedimentation of particulate matter. Cont Shelf Res 21:327-346

> Penna A, Bertuli S, Penna N, Magnani M (1999) Influence of nutrient ratios on the in vitro extracellular polysaccharide production by marine diatoms from the Adriatic Sea. J Plankton Res 21:1681-1690

> Prieto L, Sommer F, Stibor H, Koeve W (2001) Effects of planktonic copepods on transparent exopolymeric particles (TEP) abundance and size spectra. J Plankton Res 23: 515-525

Prieto L, Ruiz J, Echevarria F, Garcia CM and others (2002) Scales and processes in the aggregation of diatom blooms: high time resolution and wide size range records in a mesocosm study. Deep-Sea Res I 49:1233-1253

Prieto L, Navarro G, Cozar A, Echevarria F, Garcia CM (2006) Distribution of TEP in the euphotic and upper mesopelagic zones of the southern Iberian coasts. Deep-Sea Res II 53: 1314-1328

> Radic T, Kraus R, Fuks D, Radic J, Pecar O (2005) Transparent exopolymeric particles' distribution in the northern Adriatic and their relation to microphytoplankton biomass and composition. Sci Total Environ 353:151-161

> Ramaiah N, Furuya K (2002) Seasonal variations in phytoplankton composition and transparent exopolymer particles in a eutrophicated coastal environment. Aquat Microb Ecol 30:69-82

Ramaiah N, Yoshikawa T, Furuya K (2001) Temporal variations in transparent exopolymer particles (TEP) associated with a diatom spring bloom in a subartic ria in Japan. Mar Ecol Prog Ser 212:79-88

Schreiber U, Schliva U, Bilger W (1986) Continuous recording of photochemical and non-photochemical chlorophyll fluorescence quenching with a new type of modulation fluorometer. Photosynth Res 10:51-62

Schuster S, Herndl GJ (1995) Formation and significance of transparent exopolymer particles in the northern Adriatic Sea. Mar Ecol Prog Ser 124:227-236

Shimada A, Nakata H, Nakamura I (1997) Acidic exopolysaccharide produced by Enterobacter sp. J Ferment Bioeng 84:113-118

Smayda TJ, Reynolds CS (2001) Community assembly in marine phytoplankton: application of recent models to harmful dinoflagellate bloom. J Plankton Res 23:447-461

Smith DJ, Underwood GJC (2000) The production of extracellular carbohydrates by estuarine benthic diatoms: the effects of growth phase and light and dark treatment. J Phycol 36:321-333

> Staats N, de Winder B, Stal LJ, Mur LR (1999) Isolation and characterisation of extracellular polysaccharides from the epipelic diatoms Cylindrotheca closterium and Navicula salinarum. Eur J Phycol 34:161-169

Staats N, Stal LJ, Mur LR (2000) Exopolysaccharide production by the epipelic diatom Cylindrotheca closterium: effects of nutrient conditions. J Exp Mar Biol Ecol 249:13-27 
Suzuki N, Kato K (1953) Studies on suspended materials. Marine snow in the sea. I. Sources of marine snow. Bull Fac Fish Hokkaido Univ 4:132-135

Ter Braak CJF (1986) Canonical correspondence analysis: a new eigenvector technique for multivariate direct gradient analysis. Ecology 67:1167-1179

Ter Braak CJF, Smilauer P (2002) CANOCO Reference manual and CanoDraw for Windows User's guide: software for canonical community ordination (version 4.5). Microcomputer Power, Ithaca, NY, available at www. canoco.com

ter Braak CJF, Verdonschot PFM (1995) Canonical correspondance analysis and related multivariate methods in aquatic ecology. Aquat Sci 57:225-289

Thornton DCO (2002) Diatom aggregation in the sea: mechanisms and ecological implications. Eur J Phycol 37: 149-161

Tranvik LJ, Sherr EB, Sherr BF (1993) Uptake and utilization of 'colloidal DOM' by heterotrophic flagellates in seawater. Mar Ecol Prog Ser 92:301-309

Underwood GJC, Smith DJ (1998) Predicting epipelic diatom exopolymer concentrations in intertidal sediments from sediments chl a. Microb Ecol 35:116-125

Underwood GJC, Paterson DM, Parkes RJ (1995) The mea-

Editorial responsibility: Katherine Richardson, Copenhagen, Denmark surement of microbial carbohydrate exopolymers from intertidal sediments. Limnol Oceanogr 40:1243-1253

Underwood GJC, Nilsson C, Sundbäck K, Wulff A (1999) Short-term effects of UVB radiation on chlorophyll fluorescence, biomass, pigments and carbohydrate fractions in a benthic diatom. J Phycol 35:656-666

Underwood GJC, Boulcott M, Raines CA, Waldron K (2004) Environmental effects on exopolymer production by marine benthic diatoms: dynamics, changes in composition, and pathway of production. J Phycol 40:293-304

> Urbani R, Magaletti E, Sist P, Cicero AM (2005) Extracellular hydrocarbonates released by the marine diatoms Cylindrotheca closterium, Thalassiosira pseudonana and Skeletonema costatum: effect of P-depletion and growth status. Sci Total Environ 353:300-306

- Welch SA, Barker WW, Banfield JF (1999) Microbial extracellular polysaccharides and plagioclase dissolution. Geochim Cosmochim Acta 63:1405-1419

Welschmeyer NA (1994) Fluorometric analysis of chlorophyll $a$ in the presence of chlorophyll $b$ and pheopigments. Limnol Oceanogr 39:1985-1992

Wolfstein K, Stal LJ (2002) Production of extracellular polymeric susbtances (EPS) by benthic diatoms: effects of irradiance and temperature. Mar Ecol Prog Ser 236:13-22

Submitted: December 7, 2009; Accepted: January 20, 2011 Proofs received from author(s): April 4, 2011 